\title{
The Effect of Democratic Zoning System on Nigeria Economy: Evidence of Niger State
}

\author{
Musa Abdullahi Sakanko', Joseph David²
}

\begin{abstract}
The introduction of the zoning system into Nigeria political space was to aid the smooth rotation of key political positions across the country. This policy is to achieve fairness, peace and equitable distribution of resource. Its adverse effect on the economy is thus something to worry about. Therefore, the study examines the effect of democratic zoning system on the economy of Nigeria, with special reference to Niger state. Employing descriptive statistics and multiple regressions. The results revealed that the elements of democratic zoning vis-àvis; peace, equity, unity and justice has a positive and significant effect on the growth of the Nigeria economy. The authors thus recommends the government at both levels should focus on providing simultaneous development projects to pave way for peace and unity, zoning system should be incorporated into the Nigeria constitution, unbiased and equitable distribution of resources across the economy.
\end{abstract}

Keywords: zoning system, economic growth, political economy

\begin{abstract}
Abstrak. Pengenalan sistem zonasi ke dalam ruang politik Nigeria adalah untuk membantu kelancaran rotasi posisi politik utama di seluruh negeri. Kebijakan ini untuk mewujudkan keadilan, perdamaian dan pemerataan sumber daya. Efek buruknya terhadap ekonomi adalah sesuatu yang perlu dikhawatirkan. Oleh karena itu, studi ini meneliti pengaruh sistem zonasi demokratis terhadap ekonomi Nigeria, dengan referensi khusus ke negara bagian Niger. Mempekerjakan statistik deskriptif dan regresi berganda. Hasilnya menunjukkan bahwa unsur-unsur zonasi demokratis vis-à-vis; perdamaian, keadilan, persatuan dan keadilan memiliki dampak positif dan signifikan terhadap pertumbuhan ekonomi Nigeria. Oleh karena itu penulis merekomendasikan kepada pemerintah di kedua tingkat tersebut untuk fokus pada penyediaan proyek pembangunan simultan untuk membuka jalan bagi perdamaian dan kesatuan, sistem zonasi harus dimasukkan ke dalam konstitusi Nigeria, distribusi sumber daya yang tidak bias dan merata di seluruh ekonomi.
\end{abstract}

Kata Kunci: sistem zonasi, pertumbuhan ekonomi, ekonomi politik

\section{How to Cite:}

Sakanko, M.A., \& David, J. (2018). The Effect of Democratic Zoning System on Nigeria Economy: Evidence of Niger State. Etikonomi: Jurnal Ekonomi. Vol. 17 (1): 25 - 36. doi: http//dx.doi.org/10.15408/etk.v17i1.6592. 


\section{Introduction}

The Presidential politics in Nigeria had over the years been marred with ethnicity, tribalism, religious intolerance and electoral malpractice. Thus, led some patriotic elements in the country's polity to call for a modified and peculiar presidential system or arrangement which will enable peace, political stability and inclusive participation of all the regions in the country's politics, this is due to the feelings of the southern part of the country been marginalized as the presidential office had been historically clinched onto by the country's citizens in the northern region, and the complexity of the Nigeria society. Nigeria's aspirations have been usually centered on how to develop a broad and universally accepted framework for crisis free and equitable transfer of power including political participation, which will allow for the rotation of the six (6) key executive and legislative offices among the six (6) identifiable geographical groupings as North East, North West, North Central, South West, South East, and South-South (Omoleke, 2010). The political elites have always accused each other of various anti-democratic actions that have brought the political system to a state of near collapse.

In order to fashion out a new formula to create a basis for equitable distribution of political power through the electoral process, one of such suggestions was the proposal for the principle of zoning system, although might not be democratic nor constitutional, it has enabled inclusion of diverse groups and interests in the sharing of political power. Hence the birth of the Zoning Formula that was pictured to allow both the northern and southern region equal chances of producing a president, and was first adopted by the Shehu Shagari led second civil administration in 1979. Although the zoning system was primarily designed for the federal level, the system was equally adopted in state level and even local authorities for easy diffusion of government. Although the provision is not included in the constitution but in the act of some political parties to pave way of transparency and fairness in governing.

Zoning system or formula refers to the partitioning or division of a country into different electorate zones, which is meant to be for the purpose of rotating major political offices (among the six geo-political zones, in the case of Nigeria), opportunities and benefits, either political or socio-economic to particular region, section or zone which is aimed at ensuring effective political equity and equal representation at the federal and local level where the other geo-political zones decline to aspire to a coveted political position to the advantage of the favoured zone (Terna, 2014; Akinola, 1996; Kabuk, 2015). If the principle is perfected, it will go a long way to diffuse ethnic, religious and other sectional interests as basis for sharing political offices. Although, has slowly crept into Nigeria's political existence, dating as far back as the second Republic, though unofficially, as the Rotational system. Since then, Nigeria's political actors to achieve and attain political benefits have used it in both progressive and retrogressive manner.

This situation has posed a dilemma of sorts for Nigeria's Economic development. According to Terna (2014), the effective implementation of the zoning system tend to be a panacea for facilitating relative political and economic equity, although, the system is not suitable for long term economic planning and structuring, as it rather becomes a problem 
as it is essentially undemocratic and seriously promotes mediocrity. Advocates of zoning system often cited that peace and stability in the policy as the main reason, but Nigerians must seriously ask themselves how zoning both presidential down to even gubernatorial elections have been able to bring peace and stability (development), can zoning or quota produce the best leadership material suitable for development desperately needed at this critical time.

The zoning and rotation principle or policy is part of a democratic culture used for fair play, as it counters the negative impulse and tendency of a group of people to remain in office as long as possible and use the resources of the nation to service its narrow and practical interest, as well as antidote to a practice that engenders nepotism, promotes corruption, and breed inefficiency, which in turn stultifies growth and sustainable development. How good it might sound, the zoning system of democracy had been marred with inefficiency and corruption among the politicians, and this is because the political system of Nigeria is challenged by factor such as ethnicity, as the fear of domination of one ethnic group or section of the country has been one of the major factors inhibiting political stability in the country. Ethnicity appears to have played a more dominant role than political ideology in the choice of political leaders, and this had dire consequences on her economic development (Terna, 2014). Seemingly, the disruption of the zoning system due to the death of Umar Yar'Adua from North-west which led to Goodluck Jonathan (a southerner) becoming the president, and the lopsided political appointment under the present North-West led administration had generate serious crises, riots, vandalisation and terrorism in regions of the country thus crippling the nation's economy (Ezeibe, et al, 2016).

Niger State as state in the country, just like the six geo-political zoning in the country is partitioned into three zones, otherwise referred to as "senatorial districts", visà-vis; zone $\mathrm{A}, \mathrm{B}$, and $\mathrm{C}$. The rotation of the highest political office in the state among these zones. The governor and the deputy is not allowed to come from same zone, as such the zone that will produce the next governor shall be the one to produce deputy. This has been the setting of how the system is operating since the emerging of democracy in Niger state. The situation is disheartening as political participation is so distinctly polarized along ethnic, regional, sectional or class lines. The attempt to restore equity in the system was thus the quest for an egalitarian paradigm that has found expression in the concept of zoning which refers to concentration of opportunities and benefits, either political or socio-economic to particular region, section or zone. Thereby deselecting the other zone from Economic benefit. These are some of the issues we are experiencing with zoning system.

Zoning as a concept in Nigeria politics is aimed at ensuring political equity where the other political zones decline to aspire to a coveted political position to the advantage of the favoured zone. This is with a view that, if properly applied, such anti-developmental indices as ethnicity, religions, sectionalism etc will be relegated to the background thereby resulting into a more united and development. Furthermore, if power is allowed to systematically rotate between the various zones, the political space will not only widen, the process will definitely throw out capable leaders who can transform our country and move it to greater height. The 
rotation principles on basis of zoning also strengthen loyalty to the nation because it would guarantee access to the highest office of the land to all sections of the polity but these cannot be realized if zoning and rotation does not make fairness, equity and social justice the cardinal principle in which it is practiced. Zones must come as equal and take their turn on the basis of equity, accepting that what is good for the goose is also good for the gander. At the current level of our sociopolitical development, every patriotic Nigeria wants a country where things work. Zoning and rotation if fruitfully implemented will ensure a better Nigeria. The time may however, come when these considerations may matter less in our political considerations when we will begin to think more of merit than ethic or sectional origin. But this may wait until Nigeria becomes a nation state, bound by a chord outside "tribe and tongue" by something stronger than our own brand of "brotherhood" by then rotation and term limits may be considered anachronistic.

On this background many political office holders had participated below expectations because every incumbent government focus more priorities on his zone or people by establishing policies that will only favor the Economic development of his zone thereby deselecting the development projects from other zones. Zoning system is only critical for the sustainability of political development of democracy but not for Economic development, abandonment of existing projects from other zones, causes frictional unemployment. It is important to include political factors when analyze the economic process of the country (Radu, 2015). The political instability will have a negative effect on economic growth (Alesina, et al, 1992; Tabassam, et al, 2016).

Although the zoning democratic system in Nigeria had been in existence for decades, no empirical study had been raised to ascertain its influence or effect on the economy. Most of the scholars in the country based their study on the theoretical perspective of the subject matter while ignoring its empirical implication (see Kabuk, 2015; Ayo et al., 2012; Ezeibe, et al, 2016). The only handy empirically studies were based on the link between democracy and economy growth. Most of the studies were carried out pooling countries within same region, continent, organization together (see Rachdi and Saidi, 2015; Salahodjaev, 2015; Narayan, et al, 2011) while others where based on individual countries (see Acemoglu, Naidu, et al, 2014; Djezou, 2014). All of these didn't capture the implications of zoning system on the economy, neither was an empirical study raised to examine the influence of democracy on economic growth of Nigeria exclusively since the zoning system was imbedded into the country's political system, though unofficial until its assumed suspension under the current administration. Thus this study will capture the influence of the zoning democratic system on the growth of Nigeria's economy with special reference to the political and economy of Niger state. The objective of this study is therefore aimed at ascertaining the degree of the effects of democratic zoning system on the economy of Nigeria: Evidence of Niger State.

\section{Method}

The data used for this study were collected from a primary source, obtained from Niger state Nigeria that is the study location. The state is situated in the north central geo-political zone of Nigeria. Based on the nature of the research, a cross-sectional data will be collected 
primarily with the use of structured questionnaire. Based on the 2006 census, Niger state has an estimated population of 3,954,772, due to the large population size, using Slovin formula a sample size of 150 was obtained. Thus the stratified sampling technique will be used to collect the data. The state was partitioned into strata based on the 3 senatorial districts (Zone $\mathrm{A}, \mathrm{B}$ and $\mathrm{C}$ ) then 50 individuals will be randomly selected in each zones and from different political parties to answer the questionnaire.

In-line with the objective of this study, the functional relationship between zoning and economic growth can be represented as thus;

$$
E G R=f(\mathrm{ZNN})
$$

Where EGR denotes Economic Growth and ZNN denotes Zoning. Sincere zoning is a democratic language and the only solution to achieve peace that can be translated into fairness, equity, unity, and justice. Therefore, $Z N N$ in equation 1 would be expanded as thus:

$$
Z N N=f(P C S, E Q I, U N T, J U C)
$$

Where $P C S$ represents peace as an element of zoning; EQI is the equitable distribution of resources as a result of zoning; UNT denotes unity; and $J U C$ represents justice. In order to achieve our objective, we incorporate the elements of Zoning in equation 2 into equation 1, we obtain;

$$
E G R=f(P C S, E Q I, U N T, J U C)
$$

That is, peaceful coexistence, equitable distribution of resources, unit and justice due to zoning practice is expected to positively influence the growth of an economy.

The response variables for this study is the growth of an economy, taking the value 0 if the growth of Niger state is perceived to be declining; 1 if the growth is constant or stable and 2 if the economy is growing. The explanatory variables includes the elements of zoning system, vis-à-vis; measure of peaceful coexistence in the state sue to the zoning formulae; equitable distribution of resources across other zones not in power; unity; and justice. Therefore for empirical analysis, equation 2 will be transformed into;

$$
E G R=\lambda_{0}+\lambda_{1} P C S_{i}+\lambda_{2} E Q I_{i}+\lambda_{3} U N T_{i}+\lambda_{4} J U C_{i}+\mu_{i}
$$

Where $\lambda_{0}$ is the intercept, $\lambda_{1}-\lambda_{4}$ are the coefficient of the explanatory variables in the model; $\mu_{i}$ is the error term; other identities as previously specified. We thus employ the Ordinary Least Square (OLS) technique to estimate the parameters in the model. The choice of the model is guided by the Best Linear Unbiased Estimators (BLUE) nature of the parameter estimates of the model.

\section{Result and Discussions \\ Result}

For the purpose of this study, 150 subjects were drawn randomly and equally from each of the three zones in Niger state. As presented in Table 1, 50 respondents were randomly picked from each of the zones in the state. The current governor of the state is from zone C, while his deputy is from zone A. this is so because the zoning system in employed in Niger state do not allow both the governor and his deputy to come from same zones, as such, the 
deputy will come from the zone which will provide the next governor. When respondents are ask based on their perceived growth pattern of Niger state's economy; either its declining, steady or growing. Majority of the respondents as presented by the mean value, were of the view that the growth of Niger state's economy is steady. Only few (17 respondents) assert that the economy of the state is growing while 48 respondents agreed that the state's economy is declining. As an element of zoning system, majority of the respondents agreed that the zoning system have brought about peaceful coexistence among the people in the state, as it allows for the participation of everybody in the state, and no zone is left out of governance. Only few (45 respondents) sees the zoning system as an anti-peace mechanism.

Table 1. Descriptive Statistics

\begin{tabular}{|c|c|c|c|c|}
\hline Variables & Observation $=150$ & Mean \pm SD & Min & Max \\
\hline \multicolumn{5}{|l|}{ Zone } \\
\hline Zone A & 50 & \multirow{3}{*}{$2 \pm 0.82$} & \multirow{3}{*}{1} & \multirow{3}{*}{3} \\
\hline Zone B & 50 & & & \\
\hline Zone C & 50 & & & \\
\hline \multicolumn{5}{|c|}{ From Governor's Zone? } \\
\hline Yes & 100 & \multirow[t]{2}{*}{$0.67 \pm 0.47$} & \multirow[t]{2}{*}{0} & \multirow[t]{2}{*}{1} \\
\hline No & 50 & & & \\
\hline \multicolumn{5}{|c|}{ Economic Growth } \\
\hline Declining & 48 & \multirow{3}{*}{$0.79 \pm 0.63$} & \multirow{3}{*}{0} & \multirow{3}{*}{2} \\
\hline Steady & 85 & & & \\
\hline Growing & 17 & & & \\
\hline \multicolumn{5}{|l|}{ Peace } \\
\hline Yes & 105 & \multirow[t]{2}{*}{$0.7 \pm 0.46$} & \multirow[t]{2}{*}{0} & \multirow[t]{2}{*}{1} \\
\hline No & 45 & & & \\
\hline \multicolumn{5}{|c|}{ Resource Equitable Distribution } \\
\hline Yes & 95 & \multirow{2}{*}{$0.63 \pm 0.48$} & \multirow[t]{2}{*}{0} & \multirow[t]{2}{*}{1} \\
\hline No & $\begin{array}{l}95 \\
55\end{array}$ & & & \\
\hline \multicolumn{5}{|l|}{ Unity } \\
\hline Yes & 89 & \multirow{2}{*}{$0.59 \pm 0.49$} & \multirow[t]{2}{*}{0} & \multirow[t]{2}{*}{1} \\
\hline No & 61 & & & \\
\hline \multicolumn{5}{|c|}{ Justice in Gov't Appointments } \\
\hline Yes & 87 & \multirow[t]{2}{*}{$0.58 \pm 0.50$} & \multirow[t]{2}{*}{0} & \multirow[t]{2}{*}{1} \\
\hline No & $\begin{array}{l}81 \\
63\end{array}$ & & & \\
\hline \multicolumn{5}{|c|}{ Carrying Other Zones Along } \\
\hline Yes & & \multirow[t]{2}{*}{$0.59 \pm 0.49$} & 0 & 1 \\
\hline No & $\begin{array}{l}89 \\
61\end{array}$ & & & \\
\hline Concentra & & & & \\
\hline Yes & 101 & $0.67 \pm 0.47$ & 0 & 1 \\
\hline No & 49 & & & \\
\hline Economic & & & & \\
\hline Yes & & $0.81 \pm 0.39$ & 0 & 1 \\
\hline No & $\begin{array}{c}122 \\
28\end{array}$ & & & \\
\hline
\end{tabular}

Source: Authors Computation 
When respondents are asked about the equity in the distribution of resource by governors especially in zones which did not produce the current governor (or deputy governor), as shown by the mean value, majority of the respondents affirms to the equity in resource distribution across the state irrespective of the zone whether that of the governor (or deputy governor) or not. 55 respondents strongly disagree to the equity in resource distribution by governors. To them, governors give preference to their zones in term of resource distribution. This might not be true for all governors since they are people of different backgrounds and ideology. On whether the zoning system can further intensify unity in the state, majority of the respondents (89) strongly agree that the democratic zoning system in the state can further strengthen unity among the people. Only 61 respondents see otherwise. Based on justice in political appointments across the zones in the state, while 87 respondents were positive to this, 63 respondents disagree to this. Accordingly, 89 respondents affirm the carrying along of the entire zone in governing, irrespective of the zone that produces the head of government. In the same vein, majority of the respondents when asked if the head of government usually concentrates development project in his/her zone, affirm to this practice.

This is a common practice of giving preferential attention in terms of development project in the zone that produces the head of government, although other zone are giving considerable attention too as revealed by the 49 respondent that antagonize this view. Finally, majority of the respondents agree that the democratic zoning system practice in Niger state can lead to the growth of the economy of the state. Only 28 out of the 150 respondents were of the view that the zoning system can't propel the state's economy towards growth.

Table 2. Regression Result

\begin{tabular}{|c|c|c|c|c|}
\hline Variables & Coefficient & Standard Error & t-statistics & P-value \\
\hline Constant & -0.0813991 & 0.0765239 & -1.06 & 0.289 \\
\hline PCS & 0.288768 & 0.076664 & 3.77 & 0.000 \\
\hline EQI & 0.3773037 & 0.0774449 & 4.87 & 0.000 \\
\hline UNT & 0.2171402 & 0.0749566 & 2.90 & 0.004 \\
\hline JUC & 0.525516 & 0.079084 & 6.65 & 0.000 \\
\hline \multicolumn{5}{|c|}{$\mathrm{R}^{2}=0.58$, Adj $\mathrm{R}^{2}=0.57$, F-statistics $=50.41$, Prob. F-stat. $=0.0000$} \\
\hline \multicolumn{5}{|l|}{ Link Test } \\
\hline _hat & 1.195277 & & 4.58 & 0.000 \\
\hline _hatsq & -0.1399225 & & -0.78 & 0.439 \\
\hline \multicolumn{5}{|c|}{ Multicollinearity } \\
\hline Mean VIF & 1.22 & & & \\
\hline
\end{tabular}

Source: Authors Computation 
The regression result in Table 2 follows the model specified in equation 4 . As shown by the $\mathrm{R}^{2}$, which is a measure of goodness of fit, as, it measures the amount of deviation in the response variable along the regression line, which is explained, by the explanatory variables in the model. The 0.58 value of the $\mathrm{R}^{2}$ thus means that about $58 \%$ deviations in the response variable is explained by the explanatory variables. Accordingly, the f-statistics which measures the joint significance of the explanatory variables in the model, thus in Table 2 the value of the f-statistics with its corresponding probability value shows that all the explanatory variables are jointly significance in explaining the response variable. We employ the Link Test and the Variance Inflationary Factor (VIF) to check the adequacy of our model (using the values and p-values of hat and hatsq) and multicollinearity test respectively. From the result of postestimation test, the insignificance of hatsq means our model is correct and can be used for predictions. The mean of VIF value of 1.22 , it shows that there is no multicollinearity in the model.

From the regression result, all the factors or elements of zoning systems positively influence the growth of the economy, as such, when these elements of zoning systems are absent, the growth of the economy tend to decline as shown by the negative value of the constant term which is a measure of the response variable when all the explanatory variables in the model are assumed fixed. This result thus follows the empirical findings of Acemoglu, et al (2014); Djezou (2014); Salahodjaev (2015); Helliwell (1992); Narayan, et al (2011). This result is contrast to the empirical assertions of Rachdi and Saidi (2015). Political stability in an economy is highly important for the growth of such economy.

The element of peace in an economy poses a proportionate relationship with the growth of such economy. On average, a unit change in the element of peace in an economy will cause the economy to grow positively by $29 \%$. Investors are attracted to economies with peace, economy with crises chase investors away. People are able to carry out their economic activities effective when a considerable percentage of peace is enjoyed in an economy. This is as such statistically significance given the t-statistics and the probability value. Accordingly, equitable distribution of resources by head of government irrespective of the zone he/she comes from positively induces the economy to grow. When there is absence of inequality in resource distribution in an economy, the moral to work will be boosted, thus causing such economy to progress. On average, a unit change in the equity in resource distribution in the course of zoning system will likely lead to $38 \%$ growth in economy. Based on the t-statistics and its corresponding probability value, equity in resource distribution in the economy is statistically significant in explaining the growth of an economy. When there is that spirit of oneness among the people, irrespective of society, background and culture, brought together under the umbrella of an economy, such economy will grow positively. There is a significant link between democracy and investment. Besides that there is also a relationship between civil liberties and economic growth (Zouhaier and Karim, 2012; Knutsen, 2012).

From Table 2, a unit change in the level of unity of the people under the zoning system 
will likely cause the economy to growth by $22 \%$ significantly. Finally, justice in resource distribution and government appointments by the head of government irrespective of the zone that he/she comes from, positively induce growth in the economy. On average, a unit change in the level of justice in resource distribution and government appointments will likely cause to economy to growth by $53 \%$. Accordingly, based on the t-statistics and probability value, the variable is statistically significant in explaining the growth of the economy. When there is no perceived injustice in resource distribution and appointment, economic agents from different zones will work towards the growth of the economy, since there is a sense of belonging and one of their own is in the government representing them. Overall, as in Ezeibe, et al (2016), the exile of the zoning system in the current central government by way of sideling a region in the federal government affairs have been fingered as the main reason for vadalisation and militancy in the oil rich region of the economy which is also the mainstay of the economy, and consequent decline in oil production which have led to drastic fall in the nation's economy.

The outcome of this empirical finds could be associated with John Rawls egalitarian principle. According to him political conception of justice is worked out in a contractual procedure, where if parties bargain and agree on a fair procedure then they will accept the end product of that procedure; which means, they will accept the principles of justice without having to embrace any particular comprehensive religious or philosophical doctrine (Kabuk, 2015). Since he set to work out procedure of attaining a well-ordered society, he therefore stretched these procedural principles to embrace political rights (liberty) and social benefits (economic shares and other social goods) to the advantage of all, especially the worst off group. This end product, which he assumes to be the outcome of the rational deliberation of the contractual members, should equally be entrenched into the constitution; which is designed for a liberal democratic culture. Therefore, zoning system employed in Nigeria, specifically in Niger state have the potentials of positively inducing the economy to grow. When properly practiced, and the elements of democratic zoning system put in place, other economic variables and mechanisms of growth will automatically adjust towards the growth of the economy.

Developmental projects such as roads, schools, health care facilities, utilities, etc. should be provided equally in zones that the need is required. Considerable attention should be given to other zones, which is not responsible for providing the present head of government, as it will aid in curbing elements of disunity and distrust in the economy. Since Nigeria constitution does not recognize the zoning system and we found that is the only formula for a democratic government to achieve Socio-Economic, development and political sustainability. We then recommended the incorporation of zoning system into Nigeria constitution. By so doing, the zoning provisions will become stronger instruments if they carry the force of supreme law. Government at both levels should promote, monitor and enforce compliance with the principles of proportional sharing of all bureaucratic, economic, media and political posts at all levels of government. 


\section{Conclusion}

The zoning democratic system in Nigeria is envisage to improve unity, evenly resource distribution and representation among different regions and political strata of the economy, its subsequent suspension as a result of change in governance and party thus necessitate its effect on the economy. Thus the empirical study of the effect of democratic zoning system in Nigeria, with special reference to Niger state. Employing descriptive statistics and ordinary least square (OLS) technique for empirical analysis of 150 crosssection data collected randomly from each of the political zones in Niger state, the result obtained from the study shows that the elements of democratic zoning system, vis-à-vis; peace, equity, unity and justice have strong positive correlation with the growth of the economy. In the same vein, if not well practice, it will cause growth of an economy to decline.

The greatest challenge faced on this research work is lack of existing empirical literature to support the paper. Based on the empirical results obtained, the following recommendations are made. As an element of democratic zoning system, peace should be followed closely by the head of government, by way of fostering peace among the people from different political zones in the economy. Similarly, as an antecedent for peace and unity, resource distribution should be just and equitably distributed. The zones, which are not responsible for providing head of government in the current administration, should be seriously carried along. When appointment and resources are equitably distributed with justice, there will be sense of belonging among the people, irrespective of the zone that the head of government comes from. Development should not be concentrated only in the zone, which the head of government comes from.

\section{References}

Abubakar, D. (2004). Leadership and The Challenges of Rebuilding a Nation. In Agbaje, A., Onwudiwe, E., \& Diamond, L. (Ed). Nigeria's Struggle for Democracy and Good Governance: 153-166. Ibadan: Ibadan University Press.

Abrams, R. (1980). Foundation of Political Analysis: An Introduction to the Theory of Collective Choice. New York: Columbia Press.

Ademola, A. (2009). Ethnicity, Party Politics and Democracy in Nigeria: Peoples Democratic Party, PDP, as Agent of Consolidation?. Stud. Tribes Tribals. Vol. 7(1): 1-9.

Acemoglu, D., Naidu, S., Restrep, P. \& Robinson, J. (2014). Democracy Does Cause Growth. NBER Working Papers No. 20004. Cambridge: NBER. Retrieved from http://www. nber.org/papers/w20004.

Agbaje, A. (1998). The Ideology of Power Sharing: An Analysis of Content, Context and Intent. In Amuwo, K., Agbaje, A., Suberu, R.T., \& Herault, G. (eds.). Federalism and Political Restructuring in Nigeria: 121-136. Ibadan: Spectrum Books.

Agaptus, N. (2014). Power Rotation, Ethnic Politics and The Challenges of Democratization. Contemporary Nigeria. African Study Monographs. Vol. 35 (1): 31-40. 
Akinola, A.A. (1996). Rotational Presidency. Ibadan: Spectrum Books Ltd.

Alesina, A., Özler, S., Roubini, N., \& Swagel, P. (1992). Political Instability and Economic Growth. Journal of Economic Growth. Vol. 1 (2): 189-211. DOI: https://doi. org/10.1007/BP00138862.

Ayo, A., Olufemi, A., \& Ajinde, O. (2012). Zoning Formula and the Party Politics in Nigerian Democracy: a Crossroad for PDP in 2015 Presidential Election. International Journal of Research on Humanities and Social Sciences. Vol.2 (4): 201-210.

Djezou, W.B. (2014). The Democracy and Economic Growth Nexus: Empirical Evidence from Côte d'Ivoire. The European Journal of Comparative Economics, Vol. 11 (2): 251-266.

Ezeibe, C., Abada, I., \& Okeke, M. (2016). Zoning of Public Offices, Liberal Democracy and Economic Development in Nigeria. Mediterranean Journal of Social Sciences. Vol 7 (3): 328-337.

Helliwell, J.F. (1992). Empirical Linkages between Democracy and Economy Growth. NBER Working Paper series No. 4066. Cambridge: NBER. Retrieved from http://www.nber. org/papers/w4066.

Kabuk, V.S. (2015). Understanding the Politics of Zoning System in Nigeria: A Purview of Rawls' Complex Egalitarianism. Bassey Andah Journal. Vol. 7 (8): 139-153.

Knutsen, C.H. (2012). Democracy and Economic Growth: A Survey of Arguments and Results. International Area Studies Review. Vol. 15 (4): 393-415. DOI: https://doi. org/10.1177/2233865912455268.

Narayan, P.K., Narayan, S., \& Smyth, R. (2011). Does Democracy Facilitate Economic Growth or Does Economic Growth Facilitate Democracy? An Empirical Study of Sub-Saharan Africa. Economic Modelling. Vol. 28 (3): 900-910. DOI: https://doi.org/10.1016/j. econmod.2010.11.004.

Omoleke, I.I. (2010). The Problem of Primordial Factors and National Building. In Mangut, J., \& Egbeto, D.O. (Ed). The Fourth Republic and National Integration in Nigeria, 19992009. Makurdi: Aboki Publishers.

Pye, L. (1996). Aspects of Political Development. Boston: Little Brown.

Rachdi, H., \& Saidi, H. (2015). Democracy and Economic Growth: Evidence in MENA Countries. Procedia - Social and Behavioral Sciences. Vol. 191: 616 - 621. DOI: https:// doi.org/10.1016/j.sbspro.2015.04.644.

Radu, M. (2015). The Impact of Political Determinants on Economic Growth in CEE Countries. Procedia-Social and Behavioral Sciences. Vol. 197: 1990-1996. DOI: https:// doi.org/10.1016/j.sbspro.2015.07.579.

Salahodjaev, R. (2015). Democracy and Economic Growth: The Role of Intelligence in Cross-country Regressions. Intelligence. Vol. 50: 228-234.

Tabassam, A.H., Hashmi, S.H., \& Ur Rehman, F. (2016). Nexus Between Political Instability and Economic Growth in Pakistan. Procedia-Social and Behavioral Sciences. Vol. 230: 325-334. DOI: https://doi.org/10.1016/j.sbspro.2016.09.041. 
Terna, I. (2014). The Principle of Zoning and Its Consequences on Political Development in Nigeria. Katsina-Ala Multidisciplinary Journal. Vol. 2 (1): 51-60.

Zouhaier, H., \& Karim, K.M. (2012). Democracy, Investment and Economic Growth. International Journal of Economics and Financial Issues. Vol. 2 (3): 233-240. 